\title{
EKONOMICZNE I PRAWNE ASPEKTY WPROWADZENIA WSPÓLNEJ WALUTY EUROPEJSKIEJ POZA STREFĄ EURO ORAZ USZTYWNIANIA KURSÓW WALUT WZGLĘDEM EURO
}

\begin{abstract}
WSTĘP
W ramach procesów integracji na kontynencie europejskim 1 stycznia 1999 r. została wprowadzona wspólna waluta euro. Obecnie euro jest walutą obowiązująca nie tylko w państwach strefy euro, lecz również w innych zarówno europejskich, jak i pozaeuropejskich państwach i krajach ${ }^{1}$. Celem opracowania jest przedstawienie ekonomicznych i prawnych aspektów wprowadzenia wspólnej waluty europejskiej poza strefą euro.

Zastąpienie własnej waluty wspólną walutą europejską wymaga spełnienia określonych kryteriów ekonomicznych, a jednym z nich jest stabilizacja kursu wahań waluty narodowej przez powiązanie jej sztywnym kursem $z$ euro. W tym przypadku także istnieją państwa (zarówno europejskie, jak i pozaeuropejskie), których waluty powiązane są takim kursem z euro, mimo że państwa te w najbliższej przyszłości lub nawet nigdy nie mają zamiaru wprowadzić wspólnej waluty europejskiej. Celem opracowania jest również przedstawienie ekonomicznych i prawnych aspektów usztywniania kursów walut względem euro.
\end{abstract}

1 Termin „państwo” używany jest w dalszej części dla określenia podmiotów w pełni suwerennych, „kraj” jest pojęciem szerszym i oznacza także podmioty niesuwerenne, w tym przede wszystkim terytoria zależne państw. 


\section{WSPÓLNA WALUTA EUROPEJSKA I STREFA EURO}

Koncepcje wprowadzenia wspólnej waluty europejskiej na kontynencie europejskim zrodziły się już w dwudziestoleciu międzywojennym ${ }^{2}$ oraz $\mathrm{w}$ czasie drugiej wojny światowej podczas dyskusji na temat wizji powojennej Europy między przedstawicielami rządów emigracyjnych ${ }^{3}$. Jednak po II wojnie światowej, podczas tworzenia Europejskiej Wspólnoty Gospodarczej, która była fundamentem współczesnej UE, nie było mowy o nawet o pełnej liberalizacji przepływów kapitału czy koordynacji polityki pieniężnej, tym bardziej o wprowadzeniu wspólnej waluty europejskiej. Zacieśnienie współpracy walutowej nastąpiło na początku lat 70. XX w. i wynikało z potrzeby reakcji na załamanie się systemu z Bretton Woods. Owocami tamtej współpracy walutowej były: Europejski System Walutowy (porozumienie między bankami centralnymi dotyczące dopuszczalnego pasma wahań kursów walutowych), ECU (pierwsza, koszykowa wspólna waluta) oraz plan Wernera utworzenia unii gospodarczej i walutowej, który nie został jednak zrealizowany ${ }^{4}$.

Do koncepcji unii gospodarczej i walutowej powrócono w drugiej połowie lat 80. XX wieku w ramach planu Delorsa, który zakładał wprowadzenie wspólnej waluty jako naturalnej konsekwencji procesu tworzenia rynku wewnętrznego w ramach Europejskiej Wspólnoty Gospodarczej, a przepisy dotyczące unii gospodarczej i walutowej miały stać się częścią kolejnego traktatu. I tak podstawą prawną unii gospodarczej i walutowej stał się Traktat o Unii Europejskiej z $1992 \mathrm{r}$. (Traktat z Maastricht). Obecnie podstawę prawną unii gospodarczej i walutowej stanowi przede wszystkim Traktat o Funkcjonowaniu Unii Europejskiej (TFUE). Ponadto zgodnie z art. 3 ust. 4 Traktatu o Unii Europejskiej UE ustanawia unię

2 Wspólna waluta jako jeden z elementów systemu polityczno-gospodarczego Unii Paneuropejskiej, która miała się stać fundamentem europejskiego ładu gospodarczego i politycznego poza Ligą Narodów. Twórcą tzw. ruchu paneuropejskiego w latach 20. XX w. był austriacki książę R.N. Coudenhove-Kalergi - szerzej zob. P. Tanewski, Z historii idei Paneuropy gospodarczej, Wyd. Ekonomista, Warszawa 1997. Ponadto w 1929 r. Aristide Briand, francuski premier, wygłosił mowę na forum Ligi Narodów, w której zaproponował ideę federacji narodów europejskich opartej na solidarności i współpracy politycznej, gospodarczej i społecznej, co spotkało się z poparciem wielu wybitnych ekonomistów, wśród nich J. M. Keynesa. Jednym z elementów solidarności gospodarczej miało stać się właśnie wprowadzenie wspólnej waluty - szerzej zob. J. Łukaszewski, Cel Europa: 9 esejów o budowniczych jedności europejskiej (m.in. esej poświęcony A. Briandowi), Wyd. Nouir Sur Blanc, Warszawa 2002.

3 Genezą dyskusji było oświadczenie J. Monneta z 1943 r., członka francuskiego Narodowego Komitetu Wyzwolenia Rządu Wolnych Francuzów na uchodźstwie w Algierze, postulujące stworzenie federacji państw europejskich, ściśle ze sobą współpracujących także w sferze gospodarczej i walutowej. Szerzej zob. J. Łukaszewski, Cel Europa (m.in. esej poświęcony J. Monnetowi) oraz Twórcy zjednoczonej Europy, red. P. Borkowski, Instytut Wyd. Pax, Warszawa 2007.

4 J. Barcz, E. Kawecka-Wyrzykowska, K. Michałowska-Gorywoda, Integracja Europejska, Oficyna Wolters Kuwers Business, Warszawa, 2007, s. 276-279. 
gospodarczą i walutową, której walutą jest euro ${ }^{5}$. Unia gospodarcza i walutowa może być zatem potraktowana jako jeden $z$ celów UE.

Udział w tworzeniu unii gospodarczej i walutowej jest jednocześnie prawem i obowiązkiem każdego państwa członkowskiego UE. Jest on uwarunkowany spełnieniem przez państwo członkowskie określonych kryteriów ekonomicznych tzw. kryteriów konwergencji (wprowadzonych w II etapie realizacji planu Delorsa) $)^{6}$. Od 1 stycznia 1999 r. w trzecim etapie unii gospodarczej i walutowej uczestniczyło 11 z 15 ówczesnych państw członkowskich UE: Austria, Belgia, Finlandia, Francja, Hiszpania, Holandia, Irlandia, Luksemburg, Niemcy, Portugalia oraz Włochy. Do 1999 r. państwa te były objęte mechanizmem kursowym w ramach ERM I7. Tym samym 1 stycznia 1999 r. euro w postaci bezgotówkowej zastąpiło waluty 11 państw członkowskich UE.

Pozostałe 4 państwa członkowskiego zostały objęte regulacją szczególną ${ }^{8}$, czyli derogacją w odniesieniu do euro. W przypadku Danii (objętej wraz z Grenlandią i Wyspami Owczymi ${ }^{9}$ mechanizmem kursowym, do 1999 r. w ramach ERM I, po 1999 r. zaś w ramach ERM II) i Wielkiej Brytanii10 mamy do czynienia $z$ derogacją trwałą, gdyż jej podstawę prawną stanowią protokoły dołączone do Traktatu z Maastricht, a zatem prawo pierwotne Unii Europejskiej. Oba protokoły, po koniecznych zmianach wynikających ze zmian w TFUE, pozostały w mocy. Do Wielkiej Brytanii ma zastosowanie Protokół (nr 15) w sprawie niektórych postanowień dotyczących Zjednoczonego Królestwa Wielkiej Brytanii ${ }^{11}$, który przewiduje szczególną regulację w stosunku do tego państwa ${ }^{12}$. Nieco inne brzmienie

5 Traktat o Unii Europejskiej, wersja skonsolidowana, Dz. Urz. UE C 83 z 30.3.2010 r.

6 Dotyczą one: długu publicznego, deficytu budżetowego, inflacji, długoterminowych stóp procentowych oraz udziału w mechanizmie kursowym Europejskiego Systemu Walutowego - obecnie mechanizm ERM II (pierwotny mechanizm kursowy (zwany także ERM I) zakładał powiązanie kursów walut państw członkowskich z ECU (walutą koszykową) w celu ich stabilizacji; współczesny mechanizm kursowy (ERM II) zakłada powiązanie kursu walut narodowych z euro).

ERM I, zwany inaczej pierwotnym mechanizmem kursowym, funkcjonował przy wspólnej walucie ECU. Wraz z wprowadzeniem euro zastąpił go współczesny mechanizm kursowy, czyli ERM II.

8 Pojęciem „państwa objęte regulacją szczególną” posługuje się np. A. Nowak-Far, Unia Gospodarcza $i$ Walutowa, Wyd. C.H. Beck, Warszawa 2001, który na s. 111 tłumaczy, że termin ten lepiej odzwierciedla niemiecki tekst autentyczny, podczas gdy użycie terminu „derogacja” jest odzwierciedleniem wersji angielskiej.

9 Walutą Grenlandii jest korona duńska, a Wysp Owczych zarówno korona duńska, jak i korona Wysp Owczych związana parytetem $1: 1$ z koroną duńską.

10 Funt szterling objęty był pierwotnym ERM w latach 1990-1992.

11 Protokół został włączony do skonsolidowanej wersji traktatów. Najbardziej aktualna wersja, po zmianach wprowadzonych Traktatem z Lizbony, została opublikowana w Dzienniku Urzędowym UE C 83 z 30 marca 2010 r., s. 284.

12 Nie jest to derogacja w takim kształcie jak w stosunku do pozostałych państw. W Protokole wymieniono szereg przepisów TFUE dotyczących unii gospodarczej i walutowej, które nie będą 
ma Protokół (nr 16) w sprawie niektórych postanowien dotyczących Danii ${ }^{13}$, który przewiduje jedynie, że Dania zostaje objęta derogacją i mają zastosowanie wszystkie przepisy prawa Unii Europejskiej, które tej derogacji dotyczą. Brak w Protokole innych szczególnych przepisów dotyczących Danii. Podkreślenia wymaga, że mimo różnej konstrukcji obu Protokołów ich skutek pozostaje w zasadzie podobny. Oba państwa nie mają obowiązku przystąpienia do strefy euro, mogą jednak to zrobić na swój wyraźny wniosek. $Z$ prawnego punktu widzenia nie ma zatem możliwości objęcia tych państw wspólną walutą bez ich zgody.

W zupełnie innej sytuacji są pozostałe państwa członkowskie Unii Europejskiej objęte derogacją. Nie wynika ona bowiem w ich przypadku z prawa pierwotnego, ale jest konsekwencją faktu, że państwa te nie spełniają wszystkich - zarówno materialnych, jak i formalnych kryteriów konwergencji. Ich szczególny status nie jest bezterminowy i przynajmniej z prawnego punktu widzenia nie od tych państw zależy jego utrzymanie ${ }^{14}$.

Pierwotnie derogacją na podstawie decyzji Rady objęte były jedynie dwa państwa: Grecja i Szwecja. 1 stycznia 2001 r. Grecja po spełnieniu kryteriów konwergencji w pełni wzięła udział w tworzeniu unii gospodarczej i walutowej i rozpoczęła przygotowania do zastąpienia własnej waluty euro w tym samym terminie co pozostałe państwa członkowskie. Do 2001 r. Grecja była objęta mechanizmem kursowym - do 1999 r. w ramach pierwotnego ERM, po 1999 r. w ramach ERM II. W konsekwencji 1 stycznia 2002 r. euro w formie banknotów i monet zastąpiło waluty 12 państw członkowskich UE. Z kolei Szwecja ${ }^{15}$ pozostała członkiem objętym derogacją. Przyczyną tego nie był jednak brak spełnienia przez Szwecję kryteriów konwergencji, ale brak politycznej woli wypełnienia

miały zastosowania do Wielkiej Brytanii. Są to jednak te przepisy, których nie stosuje się do państw objętych derogacją. Ponadto w Protokole wprost stwierdzono, że niektóre artykuły (art. 134 ustęp 4 i 142 TFUE) stosuje się do Wielkiej Brytanii tak, jakby była ona objęta derogacją. Z punktu widzenia formalnego, Wielka Brytania nie jest państwem objętym derogacją, ale wydaje się, że można w tym przypadku mówić o quasi-derogacji. W punkcie 9 Protokołu (nr 15) przewidziano jednocześnie, że Wielka Brytania w każdej chwili może notyfikować swój zamiar przyjęcia euro, co będzie skutkowało utratą mocy przez przepisy Protokołu.

13 Protokół również został włączony do skonsolidowanej wersji traktatów. Aktualna wersja została opublikowana w Dzienniku Urzędowym UE C 83 z 30 marca 2010 r., s. 284.

14 Zgodnie z postanowieniami TFUE Rada, Komisja Europejska i Europejski Bank Centralny mają obowiązek monitorowania spełniania przez państwa objęte derogacją kryteriów niezbędnych do przyjęcia euro. Nie zależy to od wniosku danego państwa i teoretycznie państwo to - o ile spełnia kryteria - nie może odmówić przyjęcia wspólnej waluty. W praktyce nie jest jednak możliwe zmuszenie państwa do przyjęcia euro wbrew jego woli, co pokazuje przykład Szwecji; zob. A. Nowak-Far, op. cit., s. 329.

$15 \mathrm{Na}$ terenie gminy Hoganas środkiem płatniczym w obiegu (choć nieformalnym) obok korony szwedzkiej jest euro. 
przez to państwo wymogów formalnych ${ }^{16} .1$ maja 2004 r. do Szwecji dołączyło 10 nowych państw członkowskich, a 1 stycznia 2007 r. kolejne 2, które również otrzymały status państwa członkowskiego objętego derogacją ${ }^{17}$. Spośród tzw. nowych państw członkowskich UE euro jest obowiązującą walutą: od 1 stycznia 2007 r. w Słowenii ${ }^{18}$ (od 28 czerwca 2004 r. objęta ERM II); od 1 stycznia 2008 r. na Malcie i Cyprze ${ }^{19}$ (od 2 maja 2005 r. objęte ERM II); od 1 stycznia 2009 r. na Słowacji ${ }^{20}$ (od 28 listopada 2005 r. objęta ERM II) oraz od 1 stycznia 2011 r. w Estonii ${ }^{21}$ (od 28 czerwca 2004 r. objęta ERM II). Pozostałe nowe państwa członkowskie wraz ze Szwecją objęte są w dalszym ciągu derogacją, przy czym niektóre $\mathrm{z}$ nich zdecydowały się na udział w mechanizmie kursowym ERM II. Są to: 2 państwa bałtyckie - Litwa od 28 czerwca 2004 r. oraz Łotwa od 2 maja $2005 \mathrm{r}^{22}$

W konsekwencji, mimo że w procesie tworzenia unii gospodarczej i walutowej biorą udział wszystkie państwa członkowskie UE (27), jedynie 17 tworzy obecnie strefę euro (ang. euro zone lub euro area) ${ }^{23}$ i mają pełny wpływ na decyzje podejmowane w ramach unii gospodarczej i walutowej. Pozostałe 10 państw posiada status państwa objętego derogacją, a 3 spośród nich (oraz kraje zależne jednego z nich) uczestniczą w mechanizmie kursowym ERM II.

16 A. Nowak-Far, op. cit., s. 335.

17 J. Barcz, E. Kawecka-Wyrzykowska, K. Michałowska-Gorywoda, op. cit., s. 280-283.

18 Decyzja Rady 2006/495/WE z dnia 11 lipca 2006 r. zgodnie z art. 122 ust. 2 Traktatu w sprawie przyjęcia jednej waluty przez Słowenię z dniem 1 stycznia 2007 r., Dz. Urz. UE L 195 z 15.07.2006 r., s. 25.

19 Decyzja Rady 2007/503/WE z dnia 10 lipca 2007 r. zgodnie z art. 122 ust. 2 Traktatu w sprawie przyjęcia jednej waluty przez Cypr z dniem 1 stycznia 2008 r., Dz. Urz. UE L 186 z 18.7.2007 r., s. 29 oraz Decyzja Rady 2007/504/WE z dnia 10 lipca 2007 r. zgodnie z art. 122 ust. 2 Traktatu w sprawie przyjęcia jednej waluty przez Maltę z dniem 1 stycznia 2008 r., Dz. Urz. UE L 186 z 18.7.2007 r., s. 32. Euro znajduje się powszechnie w obiegu w tureckiej części Cypru (choć nie jest walutą formalnie obowiązującą) oraz w brytyjskiej bazie wojskowej na Cyprze Akrotiri i Dhekelie.

20 Decyzja Rady 2008/608/WE z dnia 8 lipca 2008 r. zgodnie z art. 122 ust. 2 Traktatu w sprawie przyjęcia przez Słowację jednej waluty w dniu 1 stycznia 2009 r., Dz. Urz. UE L 195 z 24.7.2008 r., s. 24.

21 Decyzja Rady 2010/416/UE z dnia 13 lipca 2010 r. zgodnie z art. 140 ust. 2 Traktatu w sprawie przyjęcia przez Estonię euro w dniu 1 stycznia 2011 r., Dz. Urz. UE L 196 z 28.7.2010 r., s. 24.

J. Barcz, E. Kawecka-Wyrzykowska, K. Michałowska-Gorywoda, op. cit., s. 280-283.

W TFUE używane jest określenie „państwa członkowskie, których walutą jest euro” (np. tytuł rozdziału $4 \mathrm{w}$ tytule VIII części III i postanowienia tego rozdziału czy art. 3 ust. 1 lit c TFUE). Jednak w niektórych przepisach pojawia się pojęcie „strefa euro” (art. 139, pkt 2a TFUE; pkt 4 Protokołu (nr 15)), które jednak nie zostało zdefiniowane. W konsekwencji określeniem najbardziej precyzyjnym pozostaje „państwa członkowskie, których walutą jest euro”, nie zaś „państwa członkowskie (członkowie) strefy euro”. Określenie „strefa euro” ma zatem charakter umowny i jest stosowane ze względów praktycznych. 
W procesach integracji walutowej uczestniczą nie tylko państwa członkowskie UE, lecz również kraje położone w różnych częściach świata. Jednak w większości są to państwa rozwijające się lub małe państwa wysoko rozwinięte. W konsekwencji żadna inna unia walutowa nie odgrywa tak istotnej roli w gospodarce światowej jak strefa euro (zob. tab. 1). Kolejnym dowodem na to, że strefa euro jest najważniejszą obecnie funkcjonującą unią walutową na świecie, jest międzynarodowy status euro. Euro, zastępując takie waluty jak marka niemiecka, frank francuski czy gulden holenderski, stosunkowo szybko stało się drugą powszechnie akceptowaną na świecie walutą międzynarodową, obok dolara amerykańskiego ${ }^{24}$. Jedną z konsekwencji bycia przez euro drugą walutą międzynarodową jest wprowadzenie euro jako waluty obowiązującej w krajach poza strefą euro oraz wiązanie kursu wielu walut krajowych właśnie z euro.

Tabela 1. Unie walutowe w gospodarce światowej

\begin{tabular}{|c|c|c|c|c|}
\hline NazWA UNII WALUTOWE* ${ }^{*}$ & NAZWA WALUTY & $\begin{array}{c}\text { PaństWa (KRAJE) NALĘ̇̇̇CE DO } \\
\text { UNII WALUTOWYCH }\end{array}$ & RoK POWSTANIA & $\begin{array}{l}\text { NAZWA INSTYTUCJI } \\
\text { PEENIACEJ FUNKCJĘ } \\
\text { BANKU CENTRALNEGO }\end{array}$ \\
\hline Strefa euro & euro & $\begin{array}{l}\text { Austria, Belgia, Niemcy, } \\
\text { Hiszpania, Finlandia, } \\
\text { Francja, Irlandia, Włochy, } \\
\text { Luksemburg, Holandia, } \\
\text { Portugalia, Grecja, } \\
\text { Słowenia, Cypr, Malta, } \\
\text { Słowacja, Estonia }\end{array}$ & 1999 & $\begin{array}{c}\text { Europejski } \\
\text { Bank Centralny } \\
\text { (European Central } \\
\text { Bank-ECB) }\end{array}$ \\
\hline $\begin{array}{l}\text { Wschodniokaraibska } \\
\text { Unia Walutowa (Strefa } \\
\text { dolara } \\
\text { wschodniokaraibskiego) }\end{array}$ & $\begin{array}{c}\text { Dolar } \\
\text { wschodniokaraibski }\end{array}$ & $\begin{array}{l}\text { Anguilla, Antigua i Bar- } \\
\text { buda, Dominika, Grenada, } \\
\text { Saint Kitts i Nevis, Saint } \\
\text { Lucia, Montserrat, Saint } \\
\text { Vincent i Grenadyny }\end{array}$ & 1965 & $\begin{array}{c}\text { ECCB (Eastern } \\
\text { Caribbean Bank) }\end{array}$ \\
\hline $\begin{array}{l}\text { Unia monetarna Szwaj- } \\
\text { carii i Liechtensteinu }\end{array}$ & Frank szwajcarski & Szwajcaria, Liechtenstein & 1920 & $\begin{array}{l}\text { Bank Centralny } \\
\text { Szwajcarii }\end{array}$ \\
\hline $\begin{array}{l}\text { Zachodnioafrykańska } \\
\text { Unia Gospodarcza } \\
\text { iWalutowa (Strefa franka } \\
\text { (FA) }\end{array}$ & $\begin{array}{c}\text { Frank CFA (CFA } \\
\text { - Communauté } \\
\text { Financie re Africaine } \\
\text { - Afrykańska } \\
\text { Wspólnota Finansowa) }\end{array}$ & $\begin{array}{l}\text { Benin, Burkina Faso, } \\
\text { Gwinea Bissau, Mali, Niger, } \\
\text { Senegal, Togo, Wybrzeże } \\
\text { Kości Słoniowej }\end{array}$ & 1994 & $\begin{array}{l}\text { BCEA0 (Banque } \\
\text { Centrale des Etats } \\
\text { de I'Afrique de } \\
\text { I'Quest }\end{array}$ \\
\hline
\end{tabular}

24 Raport na temat petnego uczestnictwa Rzeczypospolitej Polskiej w trzecim etapie Unii Gospodarczej i Walutowej, Narodowy Bank Polski, Warszawa 2009, s. 25-30. 
cd. tab. 1

\begin{tabular}{|c|c|c|c|c|}
\hline NAZWA UNII WALUTOWE* & NAZWA WALUTY & 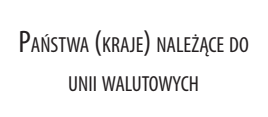 & Rok POWSTANIA & $\begin{array}{l}\text { NAZWA INSTYTUCJI } \\
\text { PEENIĄCEJ FUNKCJĘ } \\
\text { BANKU CENTRALNEGO }\end{array}$ \\
\hline $\begin{array}{l}\text { Wspólnota Ekonomiczna } \\
\text { i Monetarna Afryki } \\
\text { Centralnej (Strefa franka } \\
\text { (FA) }\end{array}$ & $\begin{array}{l}\text { Frank CFA (CFA - Com- } \\
\text { munauté Financie`re } \\
\text { Africaine - Afrykańska }\end{array}$ & $\begin{array}{c}\text { Gabon, Demokratyczna } \\
\text { Republika Kongo, Czad, } \\
\text { Republika } \\
\text { Środkowoafrykańska, } \\
\text { Kamerun, } \\
\text { Gwinea Równikowa }\end{array}$ & 1994 & $\begin{array}{c}\text { BEAC (Banque } \\
\text { Des Etats de } \\
\text { I'Afrique Centrale) }\end{array}$ \\
\hline $\begin{array}{l}\text { Strefa } \\
\text { południowoafrykańskiego } \\
\text { randa }\end{array}$ & $\begin{array}{l}\text { Rand południowoafry- } \\
\text { kański }\end{array}$ & $\begin{array}{l}\text { RPA, Lesotho, Namibia, } \\
\text { Swaziland }\end{array}$ & 1974 & $\begin{array}{c}\text { Bank Centralny } \\
\text { RPA }\end{array}$ \\
\hline $\begin{array}{l}\text { Strefa } \\
\text { franka pacyficznego } \\
\text { (CFP) }\end{array}$ & $\begin{array}{l}\text { Frank Pacyficzny } \\
\text { (CFP - Change Franc } \\
\text { Pacifique) }\end{array}$ & $\begin{array}{l}\text { Nowa Kaledonia, Polinezja } \\
\text { Francuska, Wallis i Futuna }\end{array}$ & 1945 & $\begin{array}{c}\text { IEOM } \\
\text { (Institution } \\
\text { d'Emission } \\
\text { d'Outre-Mer) }\end{array}$ \\
\hline
\end{tabular}

* Uwzględnione zostały wyłącznie unie walutowe funkcjonujące na podstawie umów międzynarodowych oraz posiadające system instytucjonalny, w skład którego wchodzi podmiot pełniący funkcje banku centralnego.

Źródło: opracowanie własne na podstawie: E. Ilzetztki, C.M. Reinhart, K.S. Rogoff, The Country Chronologies and Background Material to Exchange Rate Arrangements in the 21st Century: Which Anchor Will Hold?, IMF 2008; D. Salvatore, International Economics, Wiley, Hoboken, New Jersey 2010, s. 730-731; Ustalenia w sprawie reżimu pieniężnego $i$ kursowego między strefa euro a wybranymi krajami i terytoriami trzecimi, „Biuletyn Miesięczny Europejskiego Banku Centralnego” 2006, nr 4, s. 40.

\section{WPROWADZENIE WSPÓLNEJ WALUTY EUROPEJSKIEJ POZA STREFĄ EURO}

\section{EUROPEJSKIE PAŃSTWA MINIATUROWE}

Państwa miniaturowe ${ }^{25}$ są zwykle wyróżniane ze względu na ich małą liczbę ludności, niewielki obszar zajmowany przez nie, ale także pewien brak samodzielności politycznej będący konsekwencją dwóch pierwszych cech. Do europejskich państw miniaturowych zalicza się zazwyczaj Liechtenstein ${ }^{26}$, Monako, San Mari-

25 Terminu takiego używamy za A. Przyborowską-Klimczak, Ewolucja prawno międzynarodowej sytuacji europejskich państw miniaturowych, [w:] Prawo międzynarodowe - Problemy i wyzwania, Ksiega pamiqtkowa profesor Renaty Sonnenfeld-Tomporek, red. J. Menkes, Wyższa Szkoła Handlu i Prawa w Warszawie, Warszawa, 2006, s. 438-455, chociaż w literaturze przedmiotu można spotkać także wiele innych określeń, takich jak państwa karłowate, „minipaństwa”, „mikropaństwa” czy państwa lilipucie.

26 Liechtenstein tworzy ze Szwajcarią unię walutową (zob. tab. 1). 
no i Andorę. Na potrzeby poniższej analizy do grona tych państw zaliczyć można także Watykan ${ }^{27}$. Przed wprowadzeniem euro w czterech spośród europejskich państwach miniaturowych środkiem płatniczym były waluty narodowe państw należących obecnie do strefy euro. W Watykanie i San Marino w użyciu były liry włoskie ${ }^{28}$, w Monako franki francuskie ${ }^{29}$ oraz w Andorze franki francuskie i pesety hiszpańskie ${ }^{30}$.

San Marino, Watykan oraz Monako posiadały umowy z Włochami oraz Francją. Podstawą unii walutowej pomiędzy Monako a Francją był traktat podpisany jeszcze w 1865 r. Jeśli chodzi o San Marino, ostatnia umowa w sprawie unii monetarnej była podpisana w $1991 \mathrm{r}$. Z kolei Watykan używał waluty włoskiej zgodnie z Traktatami Laterańskimi z 1929 r. ${ }^{31}$ Z oczywistych względów po wprowadzeniu wspólnej waluty traktaty te musiały zostać zmodyfikowane. Podstawę prawną do wszczęcia negocjacji w tym zakresie stanowiła Deklaracja (nr 6) w sprawie stosunków walutowych z Republiką San Marino, Watykanem i Księstwem Monako dołączona do Traktatu z Maastricht ${ }^{32}$.

Negocjacje były prowadzone na podstawie wytycznych Rady, zawartych w decyzjach wydanych w 1999 r. W stosunku do San Marino była to Decyzja Rady 1999/97/WE z dnia 31 grudnia 1998 r. ${ }^{33}$, w stosunku do Watykanu Decyzja

27 Jest on najmniejszym państwem europejskim, jednak jego sytuacja prawnomiędzynarodowa jest szczególna w związku z powiązaniem ze Stolicą Apostolską. Stolica Apostolska jest to głowa Kościoła katolickiego, której oparcie terytorialne stanowi miasto-państwo Watykan, natomiast oba podmioty występują w stosunkach międzynarodowych zamiennie, w zależności od woli Stolicy Apostolskiej-Watykanu, R. Bierzanek, J. Symonides, Prawo międzynarodowe publiczne, Wyd. Lexis Nexis, Warszawa 2004, s. 137.

${ }_{28}$ W przypadku Watykanu legalnym środkiem płatniczym były monety emitowane przez bank centralny Włoch oraz monety emitowane w Watykanie (nałożony był limit emisji). W praktyce również banknoty włoskie były w obiegu w Watykanie, mimo że umowa nie obejmowała banknotów, a jedynie monety. Watykan nie posiada własnego banku centralnego, a instytucje finansowe Watykanu nie są objęte gwarancjami i nadzorem banku centralnego Włoch. Podobna sytuacja występowała w San Marino, z tą różnicą, że banknoty emitowane we Włoszech były legalnym środkiem płatniczym w San Marino na podstawie umowy między tymi państwami.

29 Z kolei w Monako legalnym środkiem płatniczym były zarówno banknoty i monety emitowane przez bank centralny Francji, jak i monety emitowane w Monako. Monako również nie posiada własnego banku centralnego, ale instytucje finansowe podlegały nadzorowi i gwarancjom banku centralnego Francji.

30 W Andorze status będących w obiegu franków francuskich oraz peset hiszpańskich był podobny do statusu banknotów lirów włoskich w Watykanie. Kwestia waluty nie była tam bowiem w ogóle uregulowana.

31 Szerzej o warunkach tych umów, A. Nowak-Far, op. cit., s. 388-390.

32 Dziennik Urzędowy C 191 z 29 lipca 1992 r., s. 99.

33 Council Decision 1999/97/EC of 31 December 1998 on the position to be taken by the Community regarding an agreement concerning the monetary relations with the Republic of San Marino, Dz. Urz. WE L 30, 4.2.1999, s. 33. 
Rady 1999/98/WE z dnia 31 grudnia 1998 r. ${ }^{34}$, a wobec Monako Decyzja Rady 1999/96/WE z 31 grudnia 1998 r. ${ }^{35}$ W imieniu WE negocjacje z Monako prowadziła Francja, a z San Marino i Watykanem Włochy, chociaż EBC uczestniczył w tych negocjacjach w sprawach podlegających jego kompetencji. W umowach tych miało być przewidziane nie tylko, że będą mogły one wprowadzić euro jako prawny środek płatniczy, ale także, że będą przestrzegały acquis communautaire dotyczącego euro. Pod koniec 2000 r. została zawarta umowa monetarna między Republiką Włoską, występującą w imieniu WE, oraz Republiką San Marino (podpisana 29 listopada 2000 r.) $)^{36}$, a także umowa monetarna między Republiką Włoską, występującą w imieniu WE, oraz Stolicą Apostolską, występującą z imienia Państwa Watykańskiego (podpisana 29.12.2000 r.) ${ }^{37}$. W 2003 r. Rada upoważniła Włochy do wprowadzenia poprawek w umowie z Watykanem ${ }^{38}$, które umożliwiłyby podwyższenie liczby monet euro wybijanych corocznie przez to państwo. Umowa monetarna między rządem Republiki Francuskiej, występującym w imieniu WE, i Rządem Najjaśniejszego Księcia Monako została podpisana w grudniu $2001 \mathrm{r}^{39} \mathrm{~W}$ formie wymiany listów.

Umowy te są do siebie bardzo zbliżone. Po pierwsze, zezwalają trzem państwom miniaturowym na stosowanie euro jako oficjalnej waluty, zobowiązując je przy tym do nadania banknotom i monetom euro statusu prawnego środka płatniczego z dniem 1 stycznia 2002 r. Po drugie, państwom tym nie wolno emitować banknotów, mogą natomiast emitować co roku określoną liczbę monet euro ${ }^{40}$. Po trzecie, są one zobowiązane ściśle wspólpracować z UE w zwalczaniu fałszerstw

34 Council Decision 1999/98/EC of 31 December 1998 on the position to be taken by the Community regarding an agreement concerning the monetary relations with Vatican City, Dz. Urz. WE L 30, 4.2.1999, s. 35.

35 Council Decision 1999/96/EC of 31 December 1998 on the position to be taken by the Community regarding an agreement concerning the monetary relations with the Principality of Monaco, Dz. Urz. WE L 30, 4.2.1999, s. 31.

36 Monetary Agreement between the Italian Republic, on behalf of the European Community, and the Republic of San Marino, Dz. Urz. WE C 209,27.07.2001, s. 1.

37 Monetary Agreement between the Italian Republic, on behalf of the European Community, and the Vatican City State and, on its behalf, the Holy See, Dz. Urz. WE C 299, 25.10.2001, s. 1.

38 Council Decision 2003/738/EC of 7 October 2003 on the adoption of amendments to be made to Articles 3 and 7 of the Monetary Convention between the Italian Republic, on behalf of the European Community, and the Vatican City State, represented by the Holy See, and authorising the Italian Republic to give effect to these amendments, Dz. Urz. UE L 267, 17.10.2003, s. 27.

39 Monetary Agreement between the Government of the French Republic, on behalf of the European Community, and the Government of His Serene Highness the Prince of Monaco, Dz. Urz. WE L. 142, 31.05.2002, s. 59.

40 Biciem monet dla Monako zajmuje się Hotel de la Monnaiae de Paris, dla San Marino Instituto Poligrafico e Zecca dello Stato, w Watykanie zaś Poczta Watykańska. 
banknotów i monet euro oraz do zatrzymywania i karania osób prowadzących taką działalność na ich terytorium ${ }^{41}$.

Inaczej niż w przypadku już opisanych trzech państw miniaturowych zostały ułożone stosunki monetarne pomiędzy WE/UE a Andorąa ${ }^{42} 15$ lipca 2003 r. Andora zwróciła się do WE z oficjalną prośbą o zawarcie układu monetarnego. W odpowiedzi została wydana Decyzja Rady ${ }^{43}$, w której WE zezwoliła Andorze na używanie euro w obiegu, jednak uzależniła inne przywileje, takie jak emitowanie euro, od zawarcia umowy. Jednocześnie upoważniła Komisję do rozpoczęcia negocjacji porozumienia z Andorą, przy współudziale Francji i Hiszpanii ${ }^{44}$.

Główną przyczyną wprowadzenia euro w czterech europejskich państwach miniaturowych była chęć uniknięcia kosztów transakcyjnych, zarówno w operacjach gotówkowych, jak i bezgotówkowych dokonywanych przede wszystkim z podmiotami pochodzącymi z państw, wewnątrz których lub obok których leżą Monako, San Marino, Watykan oraz Andora ${ }^{45}$. I właśnie względy pragmatyczne, czyli chęć uniknięcia ponoszenia dodatkowych kosztów, należy uznać za przyczynę wprowadzenia euro $\mathrm{w}$ czterech europejskich państwach miniaturowych. Nie bez znaczenia są też wielowiekowe i ścisłe związki gospodarcze i polityczne państw miniaturowych z Włochami, Francją oraz Hiszpanią.

\section{FRANCUSKIE TERYTORIA ZALEŻNE}

Cztery państwa członkowskie UE (Dania, Francja, Holandia oraz Wielka Brytania) utrzymują specjalne relacje $z$ krajami i terytoriami zamorskimi, będącymi

41 Ustalenia w sprawie reżimu pieniężnego i kursowego między strefa euro a wybranymi krajami i terytoriami trzecimi, „Biuletyn Miesięczny Europejskiego Banku Centralnego” 2006, nr 4, s. 34-35.

${ }_{42}$ Ma to swoje źródło w fakcie, że Andora przed wprowadzeniem euro jako wspólnej monety europejskiej nie miała uregulowanych stosunków prawnych w zakresie używanej waluty ani z Hiszpanią, ani z Francją, z którymi graniczy. Nieformalnie w obiegu znajdowały się waluty obu państw sąsiedzkich. Ponieważ 1 stycznia 2002 r. zarówno w Hiszpanii, jak i we Francji w obiegu pojawiło się euro, naturalną konsekwencją było używanie euro także w Andorze. Początkowo taki stan rzeczy nie miał żadnej podstawy prawnej.

43 Decyzja Rady 2004/548/WE z dnia 11 maja 2004 r. w sprawie stanowiska Wspólnoty odnośnie do porozumienia w kwestiach stosunków walutowych z Księstwem Andory, Dz. Urz. UE L 244 z 16.7.2004, s. 4.

44 Negocjacje zostały rozpoczęte na podstawie Decyzji Rady 2004/750/WE z dnia 21 października 2004 r. w sprawie otwarcia negocjacji w sprawie porozumienia dotyczącego stosunków walutowych z Księstwem Andory, umowa jednak dotychczas nie została zawarta, zob. Dz. Urz. UE L 332 z 6.11.2004, s. 15.

45 Posługiwanie się jedną walutą obniża koszty działania ponoszone zarówno przez przedsiębiorstwa, jak i gospodarstwa domowe. W skład tych kosztów wchodzą przede wszystkim koszty transakcyjne wymiany walut oraz koszty asekuracji przed ryzykiem kursowym. Nieponoszenie kosztów transakcyjnych wymiany walut oznacza oszczędności rzędu 0,2-0,3\% PKB. 
częścią odpowiedniego państwa członkowskiego ${ }^{46}$. Wprowadzenie wspólnej waluty europejskiej mogło mieć wpływ na terytoria należące do Francji (Polinezja Francuska, Majotta, Nowa Kaledonia, Saint Pierre i Miquelon, Wyspy Wallis i Futuna) oraz do Holandii (Aruba i Antyle Holenderskie), gdyż właśnie te dwa kraje należą do strefy euro. Spośród tych krajów i terytoriów tylko dwa posługiwały się walutą, która została zastąpiona przez euro - Majotta oraz Saint Pierre i Miqueleon, w których oficjalną walutą był frank francuski. Pozostałe francuskie kraje i terytoria zamorskie posługiwały się frankiem CFP, a holenderskie kraje i terytoria zamorskie swoimi wersjami guldenów ${ }^{47}$.

W momencie wprowadzania wspólnej waluty europejskiej Majotta oraz Saint Pierre i Miquelon nie należały do WE, a zatem euro nie zastąpiło automatycznie franka francuskiego. Potrzebne było specjalne rozwiązanie prawne, którym była decyzja Rady UE ${ }^{48}$. Na jej mocy euro z dniem 1 stycznia 1999 r. stało się oficjalną walutą Majotty oraz Saint Pierre i Miquelon, a Francja nadała banknotom i monetom euro status prawnego środka płatniczego na tych terytoriach $\mathrm{z}$ dniem 1 stycznia 2002 r. Majotta oraz Saint Pierre i Miqueloen nie uzyskały prawa do emisji własnych monet euro ${ }^{49}$. Inaczej dokonało się wprowadzenie euro w zamorskich departamentach Francji, tj. Gujanie Francuskiej, Martynice, Gwadelupie ${ }^{50}$ oraz Reunion. Departamenty te stanowią integralną część Francji i jednocześnie integralną część UE, dzięki czemu wspólną walutę wprowadzono tam jednocześnie i na tych samych warunkach co we Francji ${ }^{51}$.

O wprowadzeniu euro we francuskich krajach i terytoriach zamorskich, w których środkiem płatniczym był frank francuski, zadecydowały te same względy pragmatyczne co w przypadku europejskich państw miniaturowych. Rozszerzenie

46 Kraje i terytoria te nie należą do UE, ale są z nią w specjalny sposób stowarzyszone (tzw. stowarzyszenie konstytucyjne). Kwestię tę reguluje bezpośrednio część czwarta Traktatu o funkcjonowaniu Unii Europejskiej.

47 Ustalenia, s. 35, 40.

48 Council Decision 1999/95/EC of 31 December 1998 concerning the monetary arrangements in the French territorial communities of Saint-Pierre-et-Miquelon and Mayotte, Dz. Urz. WE L 30, 4.2.1999, s. 29.

49 Ponadto w decyzji Rady zobowiązano Francję do stosowania na obu terytoriach części prawa unijnego dotyczącego wspólnej waluty, mimo że terytoria te nie są częścią UE. Decyzja Rady dotyczyła także IEDOM (Institut d'Emmision des Departementes d' Ostre-Mer) - francuskiej instytucji publicznej, która do końca 1998 r. pełniła funkcję banku centralnego (emisja pieniądza, nadzór i gwarancje dla banków) dla Majotty oraz Saint Pierre i Miquelon. Funkcję IEDOM podtrzymano, przy czym Francja musiała dokonać pewnych reform IEDOM, tak by mógł on pełnić funkcję krajowego banku centralnego strefy euro.

${ }^{50}$ W 2008 r. od Gwadelupy oddzieliły się dwa terytoria: Saint Berthelemy oraz Saint Martin, w których również obecnie euro jest walutą obowiązującą.

51 Ustalenia, s. 37. 
obowiązywania euro na te kraje odbyło się także z odpowiednim wyprzedzeniem oraz na warunkach określonych przez Wspólnotę Europejską.

\section{PAŃSTWA BAŁKAŃSKIE}

W dotychczas omawianych krajach decyzja o wprowadzeniu euro była podejmowana $\mathrm{z}$ udziałem Unii Europejskiej. W przypadku zaś dwóch państw bałkańskich: Czarnogóry oraz Kosowa nastąpił proces decyzyjny bez udziału UE (tzw. jednostronna oficjalna euroizacja). W obu tych przypadkach nie można jednak mówić o akcie jednostronnym $\mathrm{w}$ rozumieniu prawa międzynarodowego publicznego ${ }^{52}$. $\mathrm{W}$ tym przypadku mamy zatem do czynienia $\mathrm{z}$ aktem wewnętrznym danego państwa, a nie aktem prawa międzynarodowego, jak w przypadku umów zawartych pomiędzy państwami miniaturowymi a Wspólnotą Europejską. Konsekwencją wyboru takiego rozwiązania przez te państwa jest brak wpływu na politykę państw uczestniczących w tworzeniu unii gospodarczej i walutowej. Czarnogóra i Kosowo mogą zatem używać euro jako środka płatniczego, jednakże nie mogą wydawać własnych banknotów czy bić monet ${ }^{53}$.

Serbia, Czarnogóra i Kosowo to jedyne państwa bałkańskie, w których po rozpadzie Jugosławii posługiwano się dotychczasowym dinarem jugosłowiańskim. Wszystkie trzy niezależne obecnie państwa po rozpadzie Jugosławii od 1992 r. tworzyły nową związkową Jugosławię. Tymczasowa Misja Administracyjna Narodów Zjednoczonych w Kosowie (UNIMIK), która zarządzała Kosowem od czasu wojny w Kosowie, podjęła w 1999 r. decyzję o zastąpieniu na terytorium Kosowa dinara jugosłowiańskiego przez markę niemiecką. Z kolei Czarnogóra, która w ramach państwa związkowego z Serbią dysponowała znaczną autonomią, jeszcze w 2000 r. stworzyła własny bank centralny i również zdecydowała się na zastąpienie dinara marką niemiecką. Obie decyzje miały uzasadnienie nie tylko polityczne, ale także ekonomiczne, gdyż pozwoliły na uniknięcie dalszego kryzysu gospodarczego, w którym pogrążona była Serbia pod rządami Miloševicia ${ }^{54}$.

52 Wprawdzie dotychczas nie wypracowano jednolitej definicji aktów jednostronnych, jednak autorzy są raczej zgodni co do tego, że powinien być to akt wywołujący skutki prawne w prawie międzynarodowym. Elementu tego zabrakło w przypadku decyzji o wprowadzeniu euro podjętych przez Czarnogórę i Kosowo, mimo że oczywiście wprowadzenie w tych państwach euro jako waluty obowiązującej wywołało skutki faktyczne - głównie w sferze gospodarczej; zob. W. Czapliński, A. Wyrozumska, Prawo międzynarodowe publiczne. Zagadnienia systemowe, Wyd. C. H. Beck, Warszawa, 1999, s. 91; R. Bierzanek, J. Symonides, op. cit., s. 112.

53 Nie są też związane prawem Unii Europejskiej dotyczącym aspektów technicznych, produkcji czy wycofywaniu z obiegu oraz zapobieganiu fałszerstwom banknotów i monet euro.

54 Fatalna polityka Slobodana Miloševicia, w szczególności masowe drukowanie pieniędzy bez pokrycia oraz wojna na Bałkanach, kompletnie zdyskredytowały dinara i doprowadziły do hiperinflacji. 
W 2002 r., w konsekwencji zastąpienia marki niemieckiej w obiegu gotówkowym przez euro, marka niemiecka została zastąpiona także w Czarnogórze i Kosowie ${ }^{55}$. Decyzja o korzystaniu z euro jako środka płatniczego została utrzymana przez oba państwa także po ogłoszeniu przez nie niepodległości ${ }^{56}$. W przypadku Czarnogóry wprowadzenie euro oparte jest zarówno na fundamentach ekonomicznych, jak i politycznych. Wprowadzenie euro, tożsame z redukcją kosztów transakcyjnych dla zagranicznych turystów (w szczególności pochodzących z państw strefy euro), jest czynnikiem, który wpływa na podniesienie atrakcyjności turystycznej Czarnogóry ${ }^{57}$, w której około $70 \%$ zatrudnionych pracuje w sektorze usług, z czego około połowa $\mathrm{w}$ turystyce ${ }^{58}$. Ponadto wprowadzenie euro było mniej kosztowne niż wprowadzenie waluty narodowej po rezygnacji z jugosłowiańskiego dinara. Wspólna waluta europejska stała się motorem reform systemu bankowego, a także zachętą do otwierania rachunków i lokat bankowych zarówno dla osób fizycznych, jak i przedsiębiorców ${ }^{59}$.

W przypadku Kosowa przesłanki ekonomiczne (zwłaszcza te dotyczące turystyki) miały mniejsze znaczenie niż polityczne, przede wszystkim ze względu na bardzo słabo rozwiniętą gospodarkę Kosowa. Ponadto państwo to jest w znacznym stopniu uzależnione ekonomicznie od Unii Europejskiej - 50\% bezpośrednich inwestycji zagranicznych pochodzi z państw UE. Ponadto w latach 2009-2011 Kosowo otrzyma od UE i jej państw członkowskich pomoc w wysokości 800 milionów euro ${ }^{60}$.

55 E. Bujwid-Kurek, Państwa pojugostowiańskie: szkice politologiczne, Uniwersytet Jagielloński, Kraków 2008, passim; Centralna banka Crne Gore, http://www.cb-mn.org; EBC-Eurosystem, http://www.ecb.europa.eu/euro/intro/html/index.en.html.

56 Niepodległość Czarnogóry została ogłoszona w 2006 r.w wyniku przeprowadzonego w tym państwie referendum. Z kolei Kosowo proklamowało niepodległość w lutym 2008 r. Była to decyzja o tyle kontrowersyjna, że Kosowo było wcześniej zarządzane przez UNMIK na podstawie Rezolucji Rady Bezpieczeństwa ONZ nr 1244 (1999). Z tego względu, mimo iż wiele państw uznało niepodległość Kosowa, Zgromadzenie Ogólne ONZ zwróciło się do Międzynarodowego Trybunału Sprawiedliwości (MTS) o zbadanie legalności deklaracji niepodległości Kosowa. MTS dnia 22 lipca 2010 r. potwierdził w opinii doradczej, że ogłoszenie przez Republikę Kosowa niepodległości nie stanowiło złamania prawa międzynarodowego. Zob. także Security Council resolution 1244 (1999) on the situation relating Kosovo, http://daccess-dds-ny.un.org/doc/UNDOC/GEN/N99/172/89/ PDF/N9917289.pdf?OpenElement oraz Accordance with international law of the unilateral declaration of independence in respect of Kosovo (Request for Advisory Opinion), http://http://www. icj-cij.org/docket/files/141/15987.pdf.

${ }_{57} \mathrm{Z}$ drugiej jednak strony, wprowadzenie wspólnej waluty europejskiej przyczynia się do spadku konkurencyjności cenowej (np. w porównaniu do Chorwacji).

58 Dane zaczerpnięte z CLA World Factbook 2010, http://www.cia.gov/library/publications/the-world-factbook

59 Centralna Banka Crne Gore, http://www.cb-mn.org.

${ }_{60}$ Dane za: http://ec.europa.eu/enlargement/potential-candidates/kosovo/relation/index_ en.htm. 
Podobnie jak w przypadku jednostronnej euroizacji (Czarnogóra i Kosowo) w gospodarce światowej występują procesy wprowadzania walut innego państwa jako obowiązującego środka płatniczego przy jednoczesnym braku formalnej przynależności do unii walutowej (m.in. tzw. dolaryzacja) ${ }^{61}$. Jeszcze częstszym zjawiskiem jest sztywne wiązanie waluty narodowej $\mathrm{z}$ walutami ważnymi $\mathrm{w}$ globalnym systemie walutowym, tj. dolar amerykański, euro czy funt szterling (tzw. kotwica walutowa).

\section{SZTYWNE KURSY WALUT WZGLĘDEM EURO}

\section{FRANK CFA, FRANK KOMORYJSKI, FRANK CFP ORAZ ESCUDO REPUBLIKI ZIELONEGO PRZYLĄDKA}

Frank CFA jest walutą obowiązującą w 14 afrykańskich państwach: 8 państwach członkowskich Zachodnioafrykańskiej Unii Gospodarczej i Walutowej (UEOMA) oraz 6 państwach członkowskich Wspólnoty Ekonomicznej i Monetarnej Afryki Centralnej (CEMAC). Frank CFA w latach 1948-1994 połączony był parytetem $50: 1 \mathrm{z}$ frankiem francuskim. W 1994 r. nastąpiła dewaluacja do parytetu $100: 1$, a w 1999 r. walutę odniesienia zastąpiło euro ${ }^{62}$, a zatem genezą sztywnego kursu względem euro waluty 14 państw strefy franka CFA jest przede wszystkim wspólna historia walutowa. Wraz z powstaniem unii gospodarczej i walutowej Wspólnota Europejska przejęła kompetencje zarówno w dziedzinie polityki pieniężnej, jak i kursowej. W rezultacie państwa strefy euro nie moga zawierać umów kursowych z krajami trzecimi, a kontynuacja umów kursowych sprzed 1999 r. wymaga zgody WE (obecnie zgody UE). Sytuacja ta dotyczyła umów kursowych zawartych między Francją a państwami członkowskimi UEMOA oraz CEMAC. W 1998 r. Francja wystąpiła o przedłużenie istniejących umów kursowych. Umowy dotyczyły zapewnienia wymienialności franka CFA na franki francuskie po sztywnym kursie ${ }^{63}$. Wniosek o przedłużenie tych umów kursowych oraz zastąpienie powiązania $\mathrm{z}$ frankiem francuskim powiązaniem $\mathrm{z}$ euro został przyjęty przez Radę Unii Europejskiej na podstawie Decyzji Rady 98/683/WE

61 Przykładami krajów, które zdecydowały się na taki krok, są: Wyspy Pitcairn, Niue, Wyspy Cooka (dolar nowozelandzki); Wyspy Turks i Cacoicos, Brytyjskie Wyspy Dziewicze, Panama, El Salwador, Wyspy Marshalla, Mikronezja, Ekwador, Puerto Rico (dolar amerykański); Kiribati, Nauru, Tuvalu (dolar australijski); Strefa Gazy (nowy szekel izraelski), West Bank (dinar jemeński).

62 T. Rusek, Procesy integracyjne w Afryce, [w:] Procesy integracyjne i dezintegracyjne w gospodarce światowej, red. K. Żukrowska, Szkoła Główna Handlowa w Warszawie, Warszawa 2007, s. 219.

63 Ustalenia, s. 37-38. 
$\mathrm{z}$ dnia 23 listopada $1998 \mathrm{r} .{ }^{64} \mathrm{~W}$ rezultacie $\mathrm{z}$ dniem 1 stycznia $1999 \mathrm{r}$. frank CFA został powiązany $z$ euro: $1 \mathrm{EUR}=655,957 \mathrm{XAF}$.

Z identycznych przyczyn oraz na identycznych zasadach (na mocy tej samej decyzji Rady UE) nastąpiło powiązanie waluty narodowej Komorów ze wspólną walutą europejską. Przed wprowadzeniem euro frank komoryjski (wcześniej frank komoryjsko-madagaskarski) był powiązany $\mathrm{z}$ frankiem francuskim (formalnie umową od 1979 r.; parytet wielokrotnie zmieniany), obecnie zaś 1 EUR = 491, $96775 \mathrm{KMF}$.

Sztywny kurs ustanowiony został również między euro a frankiem CFP, walutą stosowaną w Polinezji Francuskiej, Nowej Kaledonii i na Wyspach Wallis i Futuna. Terytoria te, będące częścią Francji, ale nienależące do Unii Europejskiej (wcześniej WE), lecz stowarzyszone z Unią Europejską (wcześniej WE), przed 1999 r. wiązały swoją walutę $z$ frankiem francuskim (od 1949 r. 1 XPF = 5,50 FRF, a po denominacji od 1960 r. 1 XPF = 0,055 FRF). Zmiana sztywnego kursu wobec franka francuskiego na sztywny kurs wobec euro (1 EUR = 119,332 XPF) nie wymagała decyzji Rady UE. Zmiana ta została wcześniej ustalona w Protokole w sprawie Francji dołączonym do Traktatu z Maastricht ${ }^{65}$, który zachowuje ważność także obecnie jako Protokół (nr 18) ${ }^{66}$.

$\mathrm{Z}$ podobnych przyczyn i na identycznych zasadach jak frank komoryjski i frank CFA od 1999 r. z euro sztywnym kursem powiązane jest escudo Republiki Zielonego Przylądka: 1 EUR = 110, 265 CVE. Podstawę prawną w tym przypadku stanowi Decyzja Rady 98/744/WE z dnia 21 grudnia 1998 r. ${ }^{67}$ Decyzja Rady UE umożliwiła kontynuację umowy kursowej z 1998 r. między Portugalią a Republiką Zielonego Przylądka wiążącej escudo portugalskie z escudo Zielonego Przylądka (1 PTE = 0,55 CVE; bez umowy waluty te były powiązane jeszcze w czasach, gdy Republika Zielonego Przylądka była kolonią portugalską, a także po ogłoszeniu niepodległości w 1975 r.).

64 Council Decision 98/683/EC of 23 November 1998 concerning exchange rate matters relating to the CFA Franc and the Comorian Franc, Dz. Urz. WE L 320, 28.11.1998, s. 58.

65 Treaty on European Union together with the complete text of the Treaty establishing the European Community, Protocol on France, Dz. Urz. WE C 224, 31.08.1992, s. 126.

66 Zgodnie z tym Protokołem Francja zachowała swój przywilej emisji pieniądza w Nowej Kaledonii, Polinezji Francuskiej i na wyspach Wallis i Futuna na warunkach określonych jej prawem krajowym i posiada wyłączne prawo określenia parytetu franka CFP. Tym samym Protokół daje Francji prawo emisji pieniądza w państwach wymienionych w Protokole.

${ }_{67}$ Council Decision 98/744/EC of 21 December 1998 concerning exchange rate matters relating to the Cape Verde escudo, Dz. Urz. WE L 358, 31.12.1998, s. 111. 


\section{MARKA BOŚNIACKA I LEWA BUŁGARSKA}

Po rozpadzie Jugosławii nowe niepodległe państwa wprowadziły swoje waluty: Chorwacja kunę, Słowenia tolara, Bośnia i Macedonia swoje wersje dinarów. Po wojnie, by ustabilizować zniszczoną gospodarkę Bośni i Hercegowiny, na mocy Układu z Dayton, bośniackiego dinara 21 listopada 1995 r. zastąpiła marka wymienna $^{68}$, która została sztywno powiązana z marką niemiecką (parytet $1: 1$ ). Wprowadzenie marki w miejsce dinara bośniackiego należy uznać za jeden $\mathrm{z}$ sukcesów układu pokojowego z Dayton, gdyż obecnie pozostaje ona jedną z bardziej stabilnych walut w regionie. Wraz z wprowadzeniem euro w Niemczech bośniacka marka została powiązana sztywnym kursem $\mathrm{z}$ euro: $1 \mathrm{EUR}=1,95583 \mathrm{BAM}^{69}$.

Drugim państwem bałkańskim, którego waluta jest usztywniona względem euro, jest Bułgaria. 1 lipca 1997 r. kurs bułgarskiej lewy został usztywniony względem marki niemieckiej (parytet 1:1). Powodem takiej decyzji była destabilizacja finansowa i hiperinflacja, będące efektem kryzysów bankowego, politycznego i społecznego nasilających się w transformującym się państwie. Wprowadzenie sztywnego kursu walutowego umożliwiło zwalczenie hiperinflacji, odbudowanie rezerw walutowych i stabilizację fiskalna ${ }^{70}$. Wraz z wprowadzeniem euro w Niemczech lewa bułgarska została powiązana z euro: $1 \mathrm{EUR}=1,95583 \mathrm{BGN}^{71}$.

Sztywny kurs lewy bułgarskiej i marki bośniackiej względem euro został uwarunkowany zarówno ekonomicznie, jak i historycznie. Jednakże ani Bośnia i Hercegowina ani Bułgaria nie są powiązane z Unią Europejską żadnymi umowami dotyczącymi ich kursów walutowych. Nie było także takich umów wcześniej z Niemcami. Powiązanie walut sztywnym kursem z euro w przypadku Bośni i Hercegowiny oraz Bułgarii jest zatem decyzją wewnętrzną ${ }^{72}$.

\footnotetext{
68 Oryginalna nazwa: konvertybilna marka.

69 The tenth anniversary of the Dayton accords and afterwards: reflections on post-conflict state- and nation-building, red. N. Gelazis, Woodrow Wilson International Center for Scholars, Washington 2005; Centralna banka Bosne i Hercegovine, http://www.cbbh.ba.

70 A.M. Gulde, The role of the currency board in Bulgaria's stabilization, IMF Policy Discussion Paper 99/3, Washington 1999; K.N. Pavlov, Currency board solution in Bulgaria, NATO 1999.

71 Prawo o Narodowym Banku Bułgarii z 1997 r. stanowiło automatyczne powiązanie lewy z euro, jak tylko stanie się ono środkiem płatniczym Niemiec według parytetu wynikającego z kursu marki niemieckiej względem euro - zob. Bank Centralny Bułgarii, http://www.bnb.bg.

72 Sytuacji tej nie zmieniło przystąpienie Bułgarii do Unii Europejskiej w 2007 r., którego naturalną konsekwencją jest dołączenie przez Bułgarię do grupy państw członkowskich objętych derogacją ze względu na brak spełnienia kryteriów konwergencji. Decyzja o usztywnieniu kursu waluty danego państw w stosunku do euro nie wywołuje skutków prawnomiędzynarodowych, a zatem nie rodzi konsekwencji w postaci zawiadomienia o tym fakcie organów UE czy też uzyskania ich zgody. Usztywnienie kursu lewy bułgarskiej nie ma również nic wspólnego z włączeniem waluty do ERM II.
} 


\section{ZAKOŃCZENIE}

Wprowadzenie wspólnej waluty europejskiej przyniosło konsekwencje nie tylko dla państw członkowskich UE, lecz uruchomiło również proces tzw. euroizacji, czyli zastępowania własnych walut euro przez państwa i kraje spoza strefy euro. W większości przypadków stosowanie euro nie stanowi tzw. jednostronnej euroizacji, lecz odbywa się za formalną zgodą Unii Europejskiej, choć na bazie różnych rozwiązań prawnych.

Ponadto wiele państw i krajów mających długą tradycję więzi gospodarczych i politycznych $z$ jednym $z$ państw członkowskich UE, w których walutą jest euro, powiązało własne waluty $z$ euro. Tzw. kotwice walutowe funkcjonują również na podstawie zróżnicowanych ram prawnych.

\section{BIBLIOGRAFIA}

Accordance with international law of the unilateral declaration of independence in respect of Kosovo (Request for Advisory Opinion), http://www.icj-cij.org/docket/ files/141/15987.pdf.

Barcz J., Kawecka-Wyrzykowska E., Michałowska-Gorywoda K., Integracja Europejska, Oficyna Wolters Kuwers Business, Warszawa 2007.

Bierzanek R., Simonides J., Prawo międzynarodowe publiczne, Wyd. Lexis Nexis, Warszawa 2004.

Borkowski P. (red.), Twórcy zjednoczonej Europy, Instytut Wyd. Pax, Warszawa 2007.

Bujwid-Kurek E., Państwa pojugostowiańskie: szkice politologiczne, Uniwersytet Jagielloński, Kraków 2008.

Czapliński W., Wyrozumska A., Prawo międzynarodowe publiczne. Zagadnienia systemowe, Wyd. C.H. Beck, Warszawa 1999.

Dobosiewicz Z., Geografia ekonomiczna Afryki, PWE, Warszawa 1991.

Folfas P., Przenoszenie dziatalności gospodarczej do rajów podatkowych jako strategia zarzadzania finansami korporacji transnarodowych: motywy, formy, korzyści i zagrożenia, „Bank i Kredyt” 2008, nr 12, s. 15-30.

Gelazis N. (red.), The tenth anniversary of the Dayton accords and afterwards: reflections on post-conflict state- and nation-building, Woodrow Wilson International Center for Scholars, Washington 2005.

Goetz M., Integracja krajów bytej Jugostawii z gospodarka światowa, [w:] Procesy integracyjne i dezintegracyjne w gospodarce światowej, red. K. Żukrowska, Szkoła Główna Handlowa w Warszawie, Warszawa 2007.

Gulde A.M., The role of the currency board in Bulgaria's stabilization, IMF Policy Discussion Paper 99/3, Washington 1999.

Ilzetztki E., Reinhart C.M., Rogoff K.S., The Country Chronologies and Background Material to Exchange Rate Arrangements in the 21st Century: Which Anchor Will Hold?, IMF 2008. 
Klepacki Z., Encyklopedia organizacji międzynarodowych, Książka i Wiedza, Warszawa 1975.

Eukaszewski J., Cel Europa: 9 esejów o budowniczych jedności europejskiej, Wyd. Nouir Sur Blanc, Warszawa 2002.

Nowak A., Organizacje gospodarcze krajów rozwijajacych się, [w:] T. Łoś-Nowak, Organizacje w stosunkach międzynarodowych, Uniwersytet Wrocławski, Wrocław 1999.

Nowak-Far A., Unia Gospodarcza i Walutowa, Wyd. C.H. Beck, Warszawa 2001.

Pavlov K. N., Currency board solution in Bulgaria, NATO 1999.

Przyborowska-Klimczak A., Ewolucja prawno międzynarodowej sytuacji europejskich państw miniaturowych, [w:] Prawo międzynarodowe - Problemy $i$ wyzwania, Ksiega pamiatkowa profesor Renaty Sonnenfeld-Tomporek, red. J. Menkes, Wyższa Szkoła Handlu i Prawa w Warszawie, Warszawa 2006.

Raport na temat petnego uczestnictwa Rzeczypospolitej Polskiej w trzecim etapie Unii Gospodarczej i Walutowej, Narodowy Bank Polski, Warszawa 2009.

Rogut A., Tchorek G., Dyskusja o wspólnej walucie. Koszty i korzyśsi dla Polski, „Bank i Kredyt" 2008, nr 12 (wkładka edukacyjna).

Rusek T., Procesy integracyjne w Afryce, [w:] Procesy integracyjne i dezintegracyjne w gospodarce światowej, red. K. Żukrowska, Szkoła Główna Handlowa w Warszawie, Warszawa 2007.

Salvatore D., International Economics, Wiley, Hoboken, New Jersey 2010.

Security Council resolution 1244 (1999) on the situation relating Kosovo, http://daccess-dds-ny.un.org/doc/UNDOC/GEN/N99/172/89/PDF/N9917289.pdf?OpenElement.

Tanewski P., Z historii idei Paneuropy gospodarczej, Wyd. Ekonomisty, Warszawa 1997.

Ustalenia w sprawie reżimu pieniężnego $i$ kursowego między strefa euro a wybranymi krajami i terytoriami trzecimi, „Biuletyn Miesięczny Europejskiego Banku Centralnego” 2006, nr 4, s. 31-40.

\section{AKTY PRAWNE}

Council Decision 98/683/EC of 23 November 1998 concerning exchange rate matters relating to the CFA Franc and the Comorian Franc, Dz. Urz. WE L 320, 28.11.1998, s. 58 .

Council Decision 98/744/EC of 21 December 1998 concerning exchange rate matters relating to the Cape Verde escudo, Dz. Urz. WE L 358, 31.12.1998, s. 111.

Council Decision 1999/95/EC of 31 December 1998 concerning the monetary arrangements in the French territorial communities of Saint-Pierre-et-Miquelon and Mayotte, Dz. Urz. WE L 30, 4.2.1999, s. 29.

Council Decision 1999/96/EC of 31 December 1998 on the position to be taken by the Community regarding an agreement concerning the monetary relations with the Principality of Monaco, Dz. Urz. WE L 30, 4.2.1999, s. 31.

Council Decision 1999/97/EC of 31 December 1998 on the position to be taken by the Community regarding an agreement concerning the monetary relations with the Republic of San Marino, Dz. Urz. WE L 30, 4.2.1999, s. 33. 
Council Decision 1999/98/EC of 31 December 1998 on the position to be taken by the Community regarding an agreement concerning the monetary relations with Vatican City, Dz. Urz. WE L 30, 4.2.1999, s. 35.

Council Decision 2003/738/EC of 7 October 2003 on the adoption of amendments to be made to Articles 3 and 7 of the Monetary Convention between the Italian Republic, on behalf of the European Community, and the Vatican City State, represented by the Holy See, and authorising the Italian Republic to give effect to these amendments, Dz. Urz. UE L 267, 17.10.2003, s. 27.

Decyzja Rady 2006/495/WE z dnia 11 lipca 2006 r. zgodnie z art. 122 ust. 2 Traktatu w sprawie przyjęcia jednej waluty przez Słowenię z dniem 1 stycznia 2007 r., Dz. Urz. UE L 195 z 15.07.2006, s. 25.

Decyzja Rady 2007/503/WE z dnia 10 lipca 2007 r. zgodnie z art. 122 ust. 2 Traktatu w sprawie przyjęcia jednej waluty przez Cypr z dniem 1 stycznia 2008 r., Dz. Urz. UE L 186 z 18.7.2007, s. 29 oraz Decyzja Rady 2007/504/WE z dnia 10 lipca 2007 r. zgodnie $\mathrm{z}$ art. 122 ust. 2 Traktatu w sprawie przyjęcia jednej waluty przez Maltę z dniem 1 stycznia 2008 r., Dz. Urz. UE L 186 z 18.7.2007, s. 32.

Decyzja Rady 2008/608/WE z dnia 8 lipca 2008 r. zgodnie z art. 122 ust. 2 Traktatu w sprawie przyjęcia przez Słowację jednej waluty w dniu 1 stycznia 2009 r., Dz. Urz. UE L 195 z 24.7.2008, s. 24.

Decyzja Rady 2010/416/UE z dnia 13 lipca 2010 r. zgodnie z art. 140 ust. 2 Traktatu w sprawie przyjęcia przez Estonię euro w dniu 1 stycznia 2011 r., Dz. Urz. UE L 196 z 28.7.2010, s. 24.

Monetary Agreement between the Government of the French Republic, on behalf of the European Community, and the Government of His Serene Highness the Prince of Monaco, Dz. Urz. WE L. 142, 31.05.2002, s. 59.

Monetary Agreement between the Italian Republic, on behalf of the European Community, and the Republic of San Marino, Dz. Urz. WE C 209, 27.07.2001, s. 1.

Monetary Agreement between the Italian Republic, on behalf of the European Community, and the Vatican City State and, on its behalf, the Holy See, Dz. Urz. WE C 299, 25.10.2001, s. 1.

Dziennik Urzędowy C 191 z 29 lipca 1992, s. 99.

Dz. Urz. UE L 244 z 16.7.2004, s. 4.

Dz. Urz. UE L 332 z 6.11.2004, s. 15.

Skonsolidowana wersja traktatów: Traktat o Unii Europejskiej oraz Traktat o funkcjonowaniu Unii Europejskiej, Dzienniku Urzędowy UE C 83 z 30 marca 2010 r.

Treaty on European Union together with the complete text of the Treaty establishing the European Community, Protocol on France, Dz. Urz. WE C 224, 31.08.1992, s. 126.

\section{STRONY INTERNETOWE}

Bank Centralny Bułgarii, http://www.bnb.bg

BCEAO, http://www.bceao.int

BEAC, http://www.beac.int

Centralna banka Bosne i Hercegovine, http://www.cbbh.ba 
Centralna banka Crne Gore, http://http://www.cb-mn.org

CIA World Factbook 2010 ,http://www.cia.gov/library/publications/the-world-factbook EBC-Eurosystem, /http://www.ecb.europa.eu/euro/intro/html/index.en.html

ECCB, http://www.eccb-centralbank.org

IEOM, http://www.ieom.fr

OECS, http://www.oecs.org

UE, http://ec.europa.eu/enlargement/potential-candidates/kosovo/relation/index_en.htm.

\section{EUROPEAN COMMON CURRENCY OUTSIDE THE EURO ZONE AND FIXED EXCHAN- GE RATES VS. EURO: ECONOMIC AND LEGAL ASPECTS \\ SUMMARY}

On January 1, 1999, the euro came into existence as a European common currency (currency of Economic and Monetary Union). Additionally, the euro has become legal tender in states and countries outside the euro zone. In Europe, San Marino, the Vatican, Monaco and Andorra have adopted the euro. With the introduction of the euro, it was necessary to redefine monetary relations with those countries which had no national currency but which used the former national currencies of Member States of the euro zone. The euro has become legal tender also in the French overseas departments and territories which formerly used French francs: Mayotte, Saint Pierre and Miquelon, Martinique, French Guiana, Reunion, and Guadeloupe on the basis of a decision of the Council or as integral part of France. Moreover parts of the Balkans, where the Deutschmark has been used as the official currency - Kosovo and Montenegro, on January 1,2002 also introduced the euro, however based on internal decisions, not on agreement with the EU. They can use the euro, but they are not allowed to issue banknotes and coins. Consequently, creation of the euro has launched the process of euroization - adopting the euro as legal tender outside the euro zone. Moreover, a number of states and countries, whose currency was pegged at a fixed rate to the French franc, Portuguese escudo or Deutschemark, decided to introduce fixed peg arrangements against euro. 